\title{
(Escre)ver-me numa viagem: Apontamentos sobre a metodologia que presidiu à construção de uma tese em educação artística.
}

\begin{abstract}
Resumo
Este texto procura apresentar, sob a forma de artigo, algumas das inquietações metodológicas que orientaram a produção da minha tese de doutoramento em educação artística. Através da sua escrita, apoiada numa prática de deriva, ela assumiu uma dimensão performativa na organização das ideias e conceitos apresentados, revelando-se uma estratégia inerente ao pulsar da própria investigação, facto que me permitiu desenhar uma metodologia de trabalho que ao mapear o objeto de estudo nas contingências, expansibilidades e limites da sua própria escrita, se foi revelando como uma possibilidade de fazer investigação no campo da educação artística.
\end{abstract}

Palavras-chave: educação artística, práticas de investigação, rizoma, deriva

\section{Noti(ci)ng myself on a journey: notes on the methodology that commanded the construction of a thesis on arts education.}

\begin{abstract}
This text attempts to present, in the form of a paper, some of the methodological concerns that guided the production of my doctoral thesis in arts education. Through its writing, supported by a drift practice, it assumed a performative dimension in the organization of ideas and presented concepts, disclosing itself as an inherent strategy to the pulse of the research, which allowed me to design a working methodology that, by mapping the studied object in its contingencies, expansibilities and limits of its own writing, revealed itself as a possibility for conducting research in the field of arts education.
\end{abstract}

Keywords: arts education, research practices, rhizome, drift

\section{A preparação da viagem antes da partida.}

A construção da minha tese assentou na ideia de uma viagem. Ora partindo desta analogia e embora numa viagem tenhamos uma ideia do local para onde nos queremos dirigir, o seu trajeto, no entanto, pode assumir diversos caminhos. Assim, o primeiro passo na preparação desta viagem consistiu em estudar os caminhos que já haviam sido traçados, quem os tinha percorrido e com que objetivos, para que de seguida pudesse, tendo em conta os meus propósitos, orientar conceptualmente a minha bússola para assim me posicionar criticamente ao longo do trajeto. Foi desta maneira que pude 
escolher a restante bagagem que me permitiu resistir ao longo do caminho, assim como os instrumentos de registo que me auxiliaram a memória na construção de um arquivo de estórias naquilo que é, mais do que a narração de um sentido para a viagem, a restituição do meu próprio mapa.

Estando a metodologia construída em correlação estreita com a ideia da própria tese, me parece importante, ainda que de forma breve, esclarecer o leitor sobre o propósito da mesma. Deste modo, (In)visibilidades: um estudo sobre o devir do professor-artista no ensino em artes visuais assumiu-se como um exercício de autoanálise à formação do duplo que resultou da minha relação entre artista e professor de artes visuais, no terceiro ciclo do ensino básico e secundário ${ }^{1}$. Uma ideia que se gerou enquanto docente de uma instituição de ensino particular e cooperativo que, no confronto com a minha visão de artista, desencadeou um conjunto de tensões ao nível da minha gestão social e política como professor de artes visuais, levando-me, pelo estabelecimento de uma relação reflexiva comigo mesmo, sobre um conjunto de experiências realizadas na minha prática letiva, a um desdobramento entre mim e uma imagem exterior a mim próprio: o professor-artista. Então, dizer como se produz este duplo e o que ele é, constitui o primeiro passo no sentido da sua captura. Ora se por um lado coloco a questão de como é escrever uma investigação que se faz na ação da prática artística com a educação, espaço recursivo, laboratorial e de transferência. Por outro, pergunto como se pode falar sobre ela sem a tomar como um saber instrumentalizado e, diria eu, normalizado?

Entre a 'vergonha epistemológica' e a falta de vergonha do génio, derivado 'da grande mania', a arte protege o tipo de integridade que a criou como tal, e a dotou com os seus privilégios e os seus modos de legitimidade. Os maiores paradoxos surgem quando se converte a arte em objeto de estudo, pois confrontam-se aproximações diferentes ao conhecimento, num jogo que não pode ser inocente. Deveríamos pensar como é que a paródia foi tão longe, e mobilizada por interesses que não os do seu próprio meio, passando-se a integrar nesse campo cognitivo chamado Universidade: um contexto disciplinar que requer mais do que uma paródia, ou melhor, a aceitação da paródia como formalidade...do relativismo e indeterminismo (fundamentalista) (MORAZA,2005, p.10).

Dadas as raízes da investigação que mescla os campos da arte e da educação, estou em crer que os seus investigadores continuam a ignorar a possibilidade das práticas e processos que os artistas desenvolvem, continuando a gerar um número considerável de artigos e investigações que promovem discursos e práticas hegemónicas, próximas da racionalidade do discurso científico e verdadeiro, tão inculcado na área das ciências socias e humanas (O'DONOGHUE,2009). É assim que meu ver parece existir uma grande contradição, pois se por um lado se aceita o campo artístico como ele é, incluindo até mais-valias para uma abordagem diferente ao campo educacional; por outro lado,

\footnotetext{
${ }^{1}$ Equivalente no sistema brasileiro ao ensino fundamental e médio, respetivamente.
} 
podem-se mudar os métodos ou a abordagem ao problema mas o fim em si mantêm-se: o do eterno horror ao campo da produção de incertezas. É assim que a maioria dos artigos ou investigações com que me deparei surgem revestidas por discursos onde se procura uma narrativa unificadora para o campo da educação artística em geral, e do ensino das artes visuais em particular, fazendo-nos crer que seja pela aplicação dum método mais preciso e, por isso, clarificador, que as artes encontrarão o seu lugar por direito no pedestal do conhecimento humano (VIADEL,2011). Então, sem querer:

desvalorizar o valor que as investigações trazem em si, e as teses desenvolvidas pelas 'ciências da educação' e pelas 'ciências da arte', mesmo se incapazes de quaisquer reconfigurações metodológicas perante a natureza do 'fazer artístico', defende-se aqui a concentração de esforços dos professores/artistas/investigadores na procura de outras narrativas que, alojadas nas possibilidades de acção experiencial, na dimensão em que o artístico implica sempre o 'fazer' e que o educativo representa de 'movimento relacional', evidenciem a imprescindibilidade da educação artística no deslindar das encruzilhadas do tempo, no reencontro das pessoas com o seu potencial crítico e constitutivo de outros tempos. Manter a ambiguidade de uma 'educação artística' fundamentada em premissas do modernismo e do racionalismo, em perseguições românticas do papel libertador da arte, e do valor dominante da expressão e da criatividade, não permite actualizar este privilegiado campo educativo aos conturbados tempos que vivemos (PAIVA,2012,p.166).

É neste sentido que num artigo intitulado "Processos de formação de professores artistas-reflexivos de física", se podia ler que enquanto a ciência tinha florescido pela pesquisa "de comunalidades e padrões", a arte tinha praticado a "diversidade, resistindo a encapsular as suas atividades em regras e fórmulas pré-determinadas", um pouco à semelhança da ciência mal comportada que se dedicava ao estudo de "sistemas complexos e caóticos" (QUEIROZ,2001,p.116). À ciência mal comportada, a autora referia-se à física quântica. Mas estas características do 'artístico', segundo esta autora, parecem "frutíferas para a realização de pesquisas interdisciplinares fecundas de formação de professores artistas-reflexivos em física". Porém, a autora adverte que da mesma forma que a ciência aprendeu e tirou partido da arte, esta também deveria "reconhecer as lições de regularidades da natureza, obtidas ao se buscarem comportamentos universais dentro da diversidade dos casos particulares" (Ibidem).

Como podemos ver, estas linhas de pensamento demonstram não só a tão inculcada e confortável imagem do 'artístico' como um campo ambíguo, edificado nos pressupostos do modernismo e nos discursos românticos do papel salvador da arte, do valor inato da expressão e da criatividade (FERNANDES,FERREIRA\&Ó,2007;MARTINS,2011), como também referem a necessidade da arte procurar comportamentos universais nas suas particularidades. 
Ora preferido seguir o exemplo de Nietzsche (1997), no que diz respeito a pensar e escrever sobre a minha atividade, opto por conceber dois princípios fundamentais da existência e mantê-los juntos no seu pensamento: Apolo e Dionísio; poderia dizer "ciência" e "arte", cruzando imagem e pensamento, estética e racional dentro de um mesmo plano interativo, produtivo e não contraditório. Mas para isso diria que era preciso ver a escrita como uma declaração do pensamento. Uma procura. Isto é, o pensamento é orgânico: vai e vem, segue pelo mesmo caminho, vai por outro, num continuum rizomático. Flui como a vida. Por isso temos que ver o mundo para além das evidências dicotómicas que nos são colocadas à disposição no mercado diário da vida. Um mercado de sobrevivência onde cada um antecipa o discurso do outro por forma a vencê-lo e submetê-lo a si. É o discurso do convencimento, da verdade e do poder, porque nos esquecemos que as respostas não extinguem uma pergunta. Como aponta Popkewitz, devemos é procurar perguntas (POPKEWITZ,2002,p.265), no sentido em que se esquece "que nem o homem, nem a vida, nem a natureza são domínios que se oferecem espontânea e passivamente à curiosidade do saber" (FOUCAULT,1987,p.87). A escola é que nos habituou a fazer coincidir uma pergunta com uma resposta imediata; e aqui, talvez, uma certa gaguez do pensamento fosse útil para criar fendas que nos colocassem em posição de estarmos abertos não só à cognição científica, mas também à imaginação artística fazendo com que quem nela vagueasse não se abstivesse de pensar pelos seus próprios meios e práticas.

Deste modo, sustentando um uso mais crítico da forma como professores e artistas podem escrever e pensar sobre as suas práticas, e dizer isto não é querer aqui salvar qualquer moral epistemológica ou um posicionamento superior ou alternativo às atuais metodologias de pesquisa como a Art-Based Research, Art Practice as Research, Practiceled Research, Research-led Practice in Creative Arts, Research in Education in Art \& Design, Artes y Educación, Arts-Based Educational Research, Metodologías artísticas de investigación en educación (MAIE) ou $\mathrm{A} / \mathrm{r} / \mathrm{t} /$ ography, mas sim considerar que assentar metodologicamente uma investigação num qualquer destes campos deveria significar envolver a imaginação, na formação de conceitos, que levassem a pensar melhor aquilo que queremos pensar; a nossa pergunta, a nossa angústia. É porque tenho uma pergunta que vou escrever; é porque estou a escrever que vou ler. Por conseguinte, autores distantes nas suas temáticas seriam convocados a intersetarem-se para adensarem a escrita, obrigando a deslocarmo-nos para fora do nosso pensamento numa espécie de escrita barroca. Amassar um papel e encontrar nessas dobras, colocadas num mesmo plano, linhas intersticiais que resignificassem os autores que lemos para a construção do nosso próprio pensamento, ajudando-nos a pensar melhor aquilo que queremos pensar. 
Indo buscar uma imagem ao pensamento de Jorge Larrosa (1994), aquilo que pretendi foi algo semelhante ao trabalho que se impõe diante da organização de uma biblioteca. Isto é, coloquei junto textos e ideias que à partida nada tem a ver uns com os outros, no sentido de os articular e produzir um novo sentido. Foi assim que eu, na relação entre a minha profissão e a minha mundividência, quando quis investigar sobre as práticas que desenvolvia em sala de aula me vi constantemente na necessidade de ler, escrever, filmar ou fotografar, acabando por "viver em simultâneo duas angústias; 'ruminar' o mundo a dobrar; duplicar-me em duas esferas egológicas e inventar um terceiro 'eu'" que religasse e desse "sentido à aventura investigativa" que desejava empreender (QUARESMA,2010,p.282). Por conseguinte, parece-me que mais do que esgrimir metodologias e modos de estruturação e de explanação da ação que podem conduzir à criação de discursos hegemónicos, é numa atitude crítica, reflexiva e contextualizada que os sujeitos professores e artistas poderão ganhar espaço para se reescreverem. É neste processo de constante autoanálise sobre as suas práticas em sala de aula, a partir da exterioridade de uma "escrita de si" (FOUCAULT,1994a,1994b), que acredito nos possamos pensar a nós próprios num campo aberto à investigação e à autorreflexão; podendo, através "da reflexão continuada e partilhada da atividade crítica e autocrítica da discussão em ambiente antidogmático, e do desenvolvimento do seu poder hermenêutico, conferir cada vez mais densidade, rigor, e dignidade investigativa" àquilo que nos propomos fazer (QUARESMA,2010,p.306).

Em suma, o que pretendi fazer na construção da minha tese foi, num duplo movimento, alargar a discussão a outros modos de escrever, ler e pensar sobre o fazer em educação artística e mais especificamente no ensino em artes visuais, assumindo a premência do uso das linguagens que são próprias no terreno intersubjetivo e relacional por onde se move, anulando assim as possibilidades de se deslocar o discurso para a 'tradução' do que é intraduzível - a arte, espírito da educação artística (PAIVA,2012). Neste sentido e numa entrevista concedida em 2009 ao programa Câmara Clara, transmitido pelo segundo canal da Rádio Televisão Portuguesa, Natália Pais dizia que o interessa para a educação artística na expressão matemática - " $2+2=4$ " não é o seu resultado, mas o que pode ser o seu resultado: aquilo que the dá origem, o seu processo $(1+1+1+1 ; 2 \times 2$, etc). É neste espaço em que se pensa sobre o fazer e o próprio fazer, que se isolam as tentações de tradução e de interpretação ao mesmo tempo que se aceitam as demandas experienciais e especulativas que the são próprias. Trata-se de pensar uma investigação que torna o assunto na reflexão mergulhando o problema na própria dúvida, num lugar de cumplicidade interativa e sempre tensa entre obra e discurso, um lugar aonde:

o pensamento plástico não é redutível a metodologias científicas ou a cientificação dos seus conteúdos, pois o seu axis mundi é a própria existência do ser enquanto criador de mundos, é uma área específica do 
conhecimentos humano que pressupõe trabalhar inteligência, sensibilidade, intuição, razão e emoção, dando expressão ao homem na sua totalidade (FERRÃO,2010,p.140).

Assim sendo, aquilo que procurei no processo metodológico da minha tese foi o estabelecimento de conexões, redes, paralelos e ressonâncias entre a docência e a prática artística, permitindo-me pensar a potência desta relação e as suas estruturas gramaticais, desenhando novas associações e articulações com o leitor (LATOUR,2004). E de que maneira? Escrevendo da mesma forma que labuto no meu estúdio, deixando que o pensamento me leve para onde a ação me levar. Transfigurando a formação do erudito da educação, constituindo-o menos como professor e mais como crítico da cultura. Como um artista que tem ferramentas para refletir, falar e fazer algo diferente, a começar por se questionar a si próprio que tipo de relação estabelece com o seu duplo. E aqui nada podia ser mais irónico se pensarmos que, tal como qualquer cientista das chamadas 'ciência duras', nos estaríamos a colocar num circuito de testes permanente. Ora um sujeito assim, em busca contínua de um autoconhecimento, poderia pensar uma prática docente que ao exercer-se criaria e inventaria outras possibilidades a partir da realidade existente. Reescreveria caminhos sedimentados por um longo hábito, proporia espaços lisos desenhando linhas de fuga que dispersariam a mesmice e fariam a diferença, ao mesmo tempo que potenciariam outros modos de ver e ser visto, dizer e ser dito, representar e ser representado, tendo o contentamento de nos criarmos sem nunca nos encararmos como obra acabada. É neste sentido que os sujeitos podem assumir o risco de educar-se para que o consenso nunca mais impeça os horizontes sociais de criarem espaços, recursos e sustentação para as distintas culturas que habitam o mundo, e cada um de nós, consigam emergir e falar/pensar por si próprios. Pois num sítio aonde todos pensam o mesmo, é porque alguém não pensa.

\section{Bússola conceptual e posicionamento ao longo da viagem.}

Toda a obra é uma viagem, um trajecto, mas que apenas percorre este ou aquele caminho exterior em virtude dos caminhos e trajectórias interiores que a compõem, que constituem a sua paisagem ou o seu concerto (DELEUZE,2000,p.10).

Foi desta forma que encarei o processo de construção da minha tese: como uma viagem. E uma viagem não percorre apenas vários lugares e espaços. Ela é o efeito da própria ação gerado pelo deslocamento entre vários pontos nodais. Deste modo, se numa viagem temos os mapas e as bússolas que nos orientam, nesta tese tive um conjunto de autores e conversas amigáveis, a experiência do dia-a-dia, o diário de bordo, a memória, os vídeos e as fotografias que, ao permitirem-me a elaboração de um arquivo, me possibilitaram analisar reflexivamente o meu problema, distante de uma visão 
autobiográfica. Por isso bem me recordo o quão difícil foi para mim sair do meu local de conforto, questionando as minhas representações, desterrando-me da minha cultura; pois levava na bagagem muitas das referências ocidentais que me pertenciam e me construíam. E aqui nada de mal, se eles muitas das vezes não cometessem o pecado de excesso de peso, impossibilitando-me de viajar, de 'levantar voo' e de ver o mundo como as aves em múltiplos sentidos...

Mas estas dúvidas, hesitações, refúgios e familiaridades, próprios de uma escrita calcorreante, encontram paralelo nos registos de um conjunto de exploradores e navegadores como Marco Polo, Pêro Vaz de Caminha, Fernão Mendes Pinto, Frei Cristóvão de Lisboa, Charles Darwin, entre outros. Todos eles foram viajantes aventureiros que nos trouxeram através dos seus olhares uma visão do mundo por onde passaram. E tão diferentes como eles eram os seus olhares que "interpretavam o que viam: com ingenuidade, carregado de cálculo mercantil ou de vontade de poder" conquistador, "tanto do império como da fé, com frias observações de ciência pura ou interessada, na inventariação de novos mercados" (CRISTÓVÃO,2003,p.7). Poderia dizerse que mundos visitados eram objeto de diferentes registos, consoante os agentes da escrita que se debruçavam sobre eles, ora com um olhar ingénuo, puro, autêntico e não escravo de preconceitos, ora através do olhar do poder colonizador, da desilusão, da máfé e das utopias. São estes os espantos, os perigos e as alegrias de quem ao viajar se afasta da sua cultura e se tenta desfamiliarizar. É este o alarme que se sente e o preço a pagar. Então, se numa primeira imagem me aproximei destes exploradores naquela que era a sua intenção de uma escrita etnográfica, também me afastei a partir do momento que se poderia instaurar o desejo de uma narrativa hegemónica ou colonizadora. É que neste tipo de escrita a descrição, como primeira operação etnográfica, constitui uma intensa atividade que pouco a pouco se vai complexificando numa procura da comparação com o já conhecido, para que o descrito se torne mais compreensível e aceite pelo destinatário. Já dizia Pêro Vaz de Caminha que os bons ares do Brasil eram assim frios e temperados como os de Entre Douro e Minho. Por sua vez, também Fernão Mendes Pinto afirmava que os povos da Ásia "têm pontes muito altas, compridas e largas de cantaria muito forte, feitas ao modo das nossas" (PINTO,2008,p.65). Como podemos ver é difícil deixar para trás o olhar domesticado, normalizado e pré-concebido a ver o que dele se espera. Todas estas descrições são os vestígios a que um cronista de viagens se agarra para lidar com o desconhecido, trazendo para junto de si a sua zona de conforto, a sua cultura e as suas representações, para que através deles se possa identificar com o novo e o inesperado.

Então, se num primeiro momento o meu olhar de explorador se aproximou do registo documental, do olhar limpo e transparente que apenas buscava registar, seguidamente 
deu lugar a um outro tipo de olhar infetado por determinações que se interpunham no contacto da minha cultura com o contexto encontrado. Ora esta situação se num momento inicial me levou à produção de uma zona de apaziguamento das tensões, através do reflexo de mim nos olhos do outro, também no mesmo instante através da reflexão e da experimentação comecei a questionar o que pretendiam estas representações e que tipo de visão pretendiam fabricar nos sujeitos. Foi deste modo que o meu olhar de viajante se apercebeu que só pode verdadeiramente ver quando cruzado entre os que passam e os que estão, entre os observados e os observadores. É neste transpor das fronteiras do já conhecido, que o saber se transforma e constrói, o que equivale a dizer que todo o mapa deste viajante se encontra permanentemente aberto às viagens, à experimentação de outros caminhos e à abertura de fendas, num movimento que se vai traçando no curso das articulações entre o artista, o professor, os discursos que (in)enformam as práticas e a estruturação da sua identidade.

Posto isto, desejei então que a escrita da minha tese se apresentasse como linhas de articulação e linhas de fuga, intensidades, velocidades, movimentos que territorializam e desterritorializam o pensamento. Uma escrita que acompanhasse um pensamento instável, indefinido, inquieto, que vai e volta, que não pára, que busca pensar sempre de novo e, de novo, sempre pensar. Parafraseando Gilles Deleuze e Félix Guattari (2007), deixamos para trás um espaço estrutural arborescente, onde mantínhamos bem estabelecido um tronco, à volta do qual tudo se organizava a partir de pequenos galhos e ramos, tal qual numa árvore, numa hierarquia bem estabelecida. Hoje, no entanto, vivemos mergulhados num espaço rizomático, num perfeito modelo em rede, distante de qualquer hierarquia, numa estrutura permeável e constantemente reformulável, onde vemos possibilitado o estabelecimento de todo o tipo de ligações, geradores de novo conhecimento. Da natureza de cada contacto, surgirão novos nódulos, que desde logo terão a necessidade de estabelecer novas correlações com outras estruturas, que até então Ihe eram totalmente alheias. Neste caso, escrever nada tem nada a ver com significar, mas com calcorrear e cartografar (DELEUZE \& GUATARRI,2007:23).

A ideia de escrita como rizoma implica isso mesmo. Ela não é feita de unidades, mas de dimensões, ou antes direções movediças. Não tem começo nem fim, mas tem sempre um meio, pelo qual cresce e transborda. Nesse caso, a vontade de desenlear as linhas em direção ao meu problema é querer desenhar um mapa, errar territórios longe da luz e instalar-me nas próprias linhas, sabendo que estas não param apenas na organização de um dispositivo, mas atravessam-no em todos os sentidos. Deste modo, a escrita é afim a um pensamento e inseparável de um devir. São as palavras que fazem o nosso pensamento, porque é com palavras que nós pensamos. "E pensar não é somente 'raciocinar', ou 'calcular' ou 'argumentar', como nos tem sido ensinado muitas vezes, mas 
é sobretudo dar sentido ao que somos e ao que nos acontece" (LARROSA,2002,p.21). Por isso este tipo de escritura é entendida como um processo inacabado e como movimento constante. Ela não sabe para onde vai chegar, mas sabe que não pode chegar a parte alguma porque não há onde chegar; porque o mais interessante está sempre no meio, nos desvios da viagem e nunca no início ou no fim dela. De maneira que para nos movermos e pensarmos, escrevemos, e para escrevermos, pensamo-nos e movemo-nos.

Ora as possibilidades de se construir uma escrita que tanto ilumina o objeto como o sujeito que se debruça sobre ele é, segundo Barthes (2007), uma escrita intransitiva em que o autor não escreve para dar acesso a algo independente de ambos, autor e leitor, mas escreve a si mesmo. Deste modo, podemos então dizer que esta escrita é um exercício no qual o sujeito da escrita, apenas escreve para "saber o que quer dizer (para dialogar com as ideias do seu corpo), para perder a sua consciência no ilimitado da significância (BARTHES,2009a:121). O que ele procura saber é se esse diálogo com o seu corpo o faz pensar ou não, se faz sentido, colocando-o numa posição de quem faz qualquer coisa, e não de quem fala sobre qualquer coisa (Barthes,1987). Arrisco-me assim a "escrever como um cão que faz um buraco, um rato que faz a toca", mas também a encontrar o meu "próprio ponto de subdesenvolvimento", "patoá," e "deserto" (DELEUZE\&GUATTARI,2003,p.42). Aprender está para o rato no labirinto, está para o cão que escava o seu buraco, está para alguém que procura mesmo que não saiba o quê, ou para alguém que encontra mesmo que nada tenha perdido. Mas dizer isto não significa que:

recusamos a adesão a uma dada tradição do trabalho científico, nem rejeitamos inspirar-nos e inscrever-nos num desses sistemas de regras que definem um jogo de linguagem. Chamemos-lhe, no nosso caso, jogo fenomenológico, hermenêutico, interpretativo. Dispensar-nos-emos, isso sim, de um grande trabalho legitimador de opções que parecem tomadas externamente e a priori, dado que para todo o jogo não se encontra legitimação senão no seu próprio campo (FERNANDES,2002:17).

É então que meditando entre as palavras que vemos e ouvimos, escavando buracos na língua para ver ou ouvir aquilo que está escondido, iniciamos um encontro lúcido para esta situação atlética, onde o modo de se lhe resistir criticamente, "o único modo de defender a língua" parece ser "atacá-la...cada escritor é obrigado a fazer a sua língua..." (DELEUZE citando PROUST,2000,p.16).

Barthes falava sobre a importância de ter autores estimados para escrever, aqueloutros que são modelo: "o que inspira o leitor-escritor (aquele que espera escrever) já é, para além de determinado autor amorosamente admirado, uma espécie de objeto global" (BARTHES,2005,p.22). E aqui debrucei-me sobre um conjunto de autores tal como Barthes, Deleuze, Foucault, Guattari ou Nietzsche, cujas vozes me permitiram construir 
ligações mais sustentadas para pensar aquilo que me interessava pensar. Neste sentido, Martins (2011) afirma que este tipo de perspectiva "toma os próprios textos como objetos que se inscrevem em grelhas de possibilidade, e que fazem derivar outras combinatórias no texto daquele que arrasta essas vozes para a sua própria escrita" (MARTINS,2011,p.11). É desta forma que a escrita, como pensamento, se pressagia como uma construção em permanente devir.

Na sua "Lição" (2007), texto da aula inaugural da cadeira de Semiologia Literária do Colégio de França, pronunciada em 1977, Barthes declarava-se como um sujeito incerto e impuro, inclinado com frequência a sair de um embaraço intelectual através de interrogações dirigidas ao seu prazer. E este prazer que nos fala encontra-se bem patente na produção dos seus trabalhos, onde a escrita rivaliza com a análise. É através desta lição que mais uma vez Barthes nos mostra que a linguagem é o objeto em que se inscreve o poder, refletindo a verdade para quem escreveu e leu. Mas a meu ver, é também a demonstração da tentativa de subversão do discurso. É um convite ao jogo...à caça do duplo, à fuga do estereótipo, ao logro do narrador. É neste ponto que o discurso é colocado como um desafio ao leitor, pois apresenta uma forma tanto de servidão, quanto de poder, onde "o corpo do leitor não é o corpo do escrevedor: um regressa ao outro" (BARTHES,2009a,p.98).

Foi assim que esta tese procurou gerar uma leitura que anulasse as possibilidades de existência de um centro, de um lugar privilegiado de onde derivasse um significado único e fechado. E nesta opção de não querer encontrar um lugar para o olhar pode perceberse um movimento duplo: uma leitura interior e implicada do texto, seguida de uma leitura exterior e desinteressada. Como assinalava Deleuze (2012), a constante obsessão de Foucault com o tema do duplo nunca foi uma projeção do interior mas, ao contrário, um interiorização do lado de fora (2012,p.132). Ora este é um tipo de pensamento que está a oferecer ao leitor aquilo que se projeta nas margens do texto, e que passa desapercebido como se fora escrita com tintas translúcidas e invisíveis aos olhares menos críticos. A minha postura, o meu olhar perante as fontes que apresentei foi a de um intérprete que diante de uma partitura a "sabe deslocar, agrupar, combinar, agenciar" e dar ao sujeito a possibilidade de leitura poética de si próprio. Simultaneamente, o convite que faço ao leitor "consiste em receber, em conhecer ou em experimentar esse texto, mas em escrevê-lo de novo, em atravessar a sua escrita com uma nova inscrição" (BARTHES,2009b,p.252-253). Cabe ao leitor, a meu convite, tornarse parte ativa na escuta desta autonarrativa sobre o meu devir professor-artista. Este foi um projeto de devolver o devir à escrita. Entregar o texto nas mãos do leitor que escuta, e que deixa que ele se vá fazendo. 
É graças a estas dinâmicas e intensidades que o leitor a partir desta tessitura se pode tornar um egiptólogo, um leitor das entrelinhas "porque o que com ele recolhemos da história não é algo para se tomar como definitivamente acabado", pois "samplar é andar para trás seguindo em frente" e não mais aquela atitude de preservar em formol (FADIGAS,2003,p.63). Por isso ler é sempre compreender outros textos já lidos, mas situados em outros locais. A única coisa que pode revelar este sistema é o ato de ler, já que no plano do texto não há um sujeito ativo - o escritor -, perante alguém passivo - o leitor. O texto determina as atitudes gramaticais através das quais o olho indiferenciado "com que eu vejo Deus é o mesmo olho com que ele me vê" (BARTHES,2009a:140). O leitor poderá assim espessar, na leitura dos textos e do arquivo, o trabalho de tessitura e de análise reflexiva de que eles são produto, já que os autores que mobilizei foram "considerados unicamente a partir do seu lugar enquanto instauradores de um discurso que se torna produtivo, porque o é na potência que oferece à sua transformação pelo exercício contínuo" com que (re)desenharam o meu pensamento (MARTINS,2011,p.11). E essas transformações, segundo esta autora, não se dão "pelo princípio da originalidade do autor e da obra, mas antes pelas construções teóricas que aquele que escreve é capaz de empreender" (MARTINS,2011,p.40). Tudo o que quis foi experimentar com esta tribo de autores, jogar com os seus pensamentos, movimentar as suas ideias. Tudo teve a ver com experimentação, ação e multiplicidade. Assim, mais do que justificar pretendi sugerir, mais do que comprovar, desejei incitar, e mais do que descrever tentei analisar, pois "a escrita acontece sempre que as palavras tenham sabor"2 (BARTHES,2007,p.19).

Instrumentos de registo: a entrevista, o diário, a fotografia e o vídeo.

Em concordância com a orientação política da gestão desta viagem, também os instrumentos de registo que a seguir se anunciam foram surgindo espontaneamente e de acordo com as necessidades que o trajeto da mesma reclamava. Assim sendo, da imensa variedade de classificações que as ciências sociais têm atribuído às entrevistas, considerei particularmente útil e esclarecedora para este estudo a forma como foram colhidos os depoimentos que compõem La Misère du Monde, livro de Pierre Bourdieu (2007). Isto porque, como salienta o próprio autor:

Muitas dezenas de anos de prática da pesquisa sob todas as formas, da etnologia à sociologia, do questionário dito fechado à entrevista mais aberta, convenceram-me que esta prática não encontra sua expressão adequada nem nas prescrições de uma metodologia frequentemente mais cientista que científica, nem nas preocupações anticientíficas das místicas da fusão afetiva (2007,p.693).

\footnotetext{
2 "(saber e sabor têm a mesma etimologia em latim: sapere, que significa ter gosto; exalar cheiro, um odor; fig.: conhecer, compreender)" (Barthes,2007,p.19).
} 
A opção feita por Bourdieu (2007) neste livro foi a de intensificar a proximidade social e cultural entre entrevistados e entrevistadores (que teriam sido incentivados, inclusive, a entrevistar amigos e parentes), reduzindo, portanto, o distanciamento comum neste tipo de método. Esta postura permitiu-me uma excessiva interferência no discurso do interlocutor, assim como inversões no meu papel que, ao colocar-me atrás da voz do entrevistado, ficava reduzido a um écrivan public; a quem cabe apenas apresentar, sem trair, as mensagens que Ihe são confiadas.

$\mathrm{Na}$ mesma linha de pensamento, também Kaufmann (1996), em L'entretien compréhensif, apresentava-me um tipo de entrevista envolto num método mole (por oposição às ciências ditas duras), empírico e subjetivo, propondo uma reflexão entre a teoria, o método e o campo de estudo. Para Kaufmann, a entrevista assume-se como uma ferramenta de articulação entre a literatura e as observações no terreno, onde as reflexões e os questionamentos que daí emergem são constantemente confrontados com essa mesma realidade. É, portanto, um género de entrevista feito num de registro de conversa aberta e 'compreensiva', que exige uma proximidade entre o entrevistador e o entrevistado, para um compromisso mútuo na busca de informação. Evita-se assim propositadamente a neutralidade comum e a distância, encorajando o entrevistado e o entrevistador a encadear a conversa e a informação no sentido de "expressar seu mais profundo conhecimento" sobre o assunto em questão. Neste caso:

O sonho positivista de uma perfeita inocência epistemológica oculta na verdade que a diferença não é entre a ciência que realiza uma construção e aquela que não o faz, mas entre aquela que o faz sem saber e aquela que, sabendo, se esforça para conhecer e dominar o mais completamente possível seus atos, inevitáveis, de construção e os efeitos que eles produzem inevitavelmente (BOURDIEU,2007,p.694-695).

A ideia seria encarar estas entrevistas como conversas amigáveis, promovendo uma "escuta ativa e metódica" ao mesmo tempo que se reduziria a "violência simbólica" do discurso. Seria nestas condições que se esperava que surgissem situações de comunicação excecionais, livres de constrangimentos, principalmente temporais, abrindo ao entrevistado oportunidades que o incitavam a exprimir situações que geravam novas ideias provocadas pela interação do discurso (BOURDIEU,2007).

Como forma de extrair ao entrevistado estas novas ideias e aplicá-las ou devolvê-las ao campo de ação da minha prática letiva, considerei incluir a entrevista de explicitação ao meu processo de pesquisa. Segundo Vermersch (1994), L'entretien d'explicitation (doravante designada como: a entrevista de explicitação), tem como objetivo a verbalização da ação. Através desta prática passamos em viés à pergunta 'porquê' (à espera de uma resposta para validar a compreensão de um problema), para colocar as questões da forma 'como' (compreender o funcionamento do entrevistado em situações 
de ação no terreno da sua prática). Esta concepção de entrevista centra-se na explicação da ação ao vivo e, mais especificamente, nas informações de natureza processual a fim de reconstruir a estrutura da ação. Este tipo de abordagem permite operar a reflexão desta informação a partir do plano do sujeito vivido, em termos da sua representação, conduzindo-o assim a um processo de análise próximo de uma autoscopia. Para isso é necessário recorrer a acontecimentos concretos, a memórias e experiências que permitam o contacto do acontecimento passado com um tempo definido. Por tudo isto posso dizer que a entrevista de explicitação estabelece uma prática relacional entre o entrevistador e o entrevistado, já que ela permite que cada um destes atores entre em atividade e em auto-mobilidade orientada por um objetivo próprio. Pois se por um lado para os entrevistados as verbalizações provocadas na interação permitem um retorno reflexivo para o trabalho da sua ação, por outro, a recolha da informação para mim, muitas vezes desviante do meu percurso latente, também me permite reorientar a minha pesquisa.

Deste modo sob risco de chocar tanto os metodólogos rigoristas quantos os hermeneutas inspirados, eu diria naturalmente que a entrevista pode ser considerada como uma forma de exercício espiritual, visando obter, pelo esquecimento de si, uma verdadeira conversão do olhar que lançamos sobre os outros nas circunstâncias comuns da vida. A disposição acolhedora que inclina a fazer seus os problemas do pesquisado, a aptidão a aceitá-lo e a compreendê-lo tal como ele é, na sua necessidade singular é uma espécie de amor intelectual [...] (Bourdieu,2007,p.704).

Encarar a entrevista nestes pressupostos faz com que a parceria entre 'entrevistado' e 'entrevistador' crie uma diferenciação ou uma não-simetria, devido às diferentes funções que a entrevista de explicitação cria para ambos os jogadores. Foi desta forma que as entrevistas que realizei seguiram um guião de perguntas que foram sendo sucessivamente alteradas no decorrer da própria entrevista, do mesmo modo que foram sendo alteradas de entrevista para entrevista. Como disse, o fito principal da utilização da entrevista era garantir, através de uma conversa amigável e residual, uma troca informal de ideias, um encaminhamento conceptual, bibliográfico, etc., moldando a minha compreensão sobre o assunto que investigava. O que procurava, mais do que "a reflexividade que é sinónimo de método", era "uma reflexividade reflexa, baseada num 'trabalho', num 'olho' sociológico" que deixa "perceber e controlar no campo, na própria condução da entrevista, os efeitos da estrutura social na qual se realiza" (BOURDIEU,2007,p.694). Por conseguinte, tinha de explorar um outro caminho antes de partir para a escavação destes sedimentos, revendo o meu diário gráfico e fotográfico de forma a recolocar o meu problema no centro da minha investigação, dado que escolher um caminho é sempre uma opção política. Como salienta Luís Fernandes:

Quem tem, por obrigação profissional, de selecionar métodos e aplicar técnicas e de andar zelosamente à cata de razões teórico-epistemológicas 
que the fundamentem as escolhas, acaba por perceber que afinal a defesa de um método - de qualquer método - depende da argumentação. E da argumentação depende o consenso, que é um dos critérios principais de adesão dos cientistas às práticas que se entregarão. [...] Assim como todo o objeto só existe no/pelo discurso (FERNANDES,2002,p.17-18).

Ora a entrada do diário nesta investigação faz-se através duma construção dinâmica baseada na imagem e na escrita, exercício que se revelou fundamental para uma autoanálise do problema em estudo, a minha autoconstrução como professor-artista, já que me capacitava para uma nova forma de encarar os problemas através de um processo continuum de autoscopia. Mais uma vez a intenção deste tipo de trabalho foi explicitar e interpretar as minhas movimentações, exigindo observação, reflexão, vigilância e autocrítica. Se todos nós quotidianamente refletimos sobre o que se passa à nossa volta, o meu olhar de fotógrafo tinha o papel de ler e interpretar a realidade de uma forma sistemática e intencional, estando atento particularmente aos pormenores aparentemente mais insignificantes. Contudo, a intencionalidade da observação atenta e o estabelecimento (des)interessado das relações humanas por parte deste olhar levantavam desde logo algumas questões na investigação. Como não me sentir, por exemplo, um espectador indiscreto a espreitar a intimidade alheia para a tornar pública; ou um fingidor a falsear amizades sinceras? No meu entender este obstáculo foi facilmente transposto, dado que, sob o foco do meu posicionamento conceptual, a etnografia não foi encarada apenas como um método de investigação, mas como uma forma de estar na vida através da observação, da curiosidade, da reflexão. Daí que quando liguei esta pesquisa ao fotográfico e expliquei aos entrevistados as razões pelas quais iria filmar e fotografar as aulas/sessões, eles assumiram precisamente isso. Como uma curiosidade do artista em perceber mais sobre o seu trabalho; e uma vontade do professor em saber mais sobre aquilo que está a ensinar.

Foi então que defini como estratégia desenvolver um diário no qual registaria os meus pensamentos, movimentações e reflexões, pois o recurso à escrita e à imagem, como registro da processualidade, interessava-me como ferramenta que acompanha o desfiar de certos mundos e a própria construção e formação de outros, como um mapa ou um puzzle que vai desenhando o caminho trilhado e direcionando a construção da sua própria formação. Esta prática permitia-me estabelecer um jogo de reflexão entre mim, os alunos e as suas coreografias, permitindo um refinamento da minha prática. E aqui gostaria de aprofundar um pouco a noção de diário escrito ou desenhado, concebendo-o "como um adestramento de si por si mesmo" (FOUCAULT,2006,p.132). Uma "escrita de si", associada a um exercício de pensamento e meditação, onde a escrita surge como a maneira de recolher a leitura feita. Para isso, recorri às duas formas consideradas por Foucault: i) como uma espécie de hypomnemata, um caderno diário aonde o indivíduo regista sua conduta, levando-o futuramente, graças a um exame de consciência, a 
corrigi-la através da "constituição de si a partir da recolha do discurso dos outros" (Ibidem:152); ii) como correspondência, já que serviu de meio para comunicar a alguém as imperfeições e vitórias quotidianas, recebendo em troca a crítica ou o incentivo desejados e, ultrapassando os constrangimentos da "manifestação de uma escrita íntima individual" (VANCRAYENEST,1990,p.5).

Perante esta imagem situei o meu diário no primeiro formato, enquanto neste último integrei as reflexões escritas pelos alunos em torno das propostas e das relações que se geraram. Tanto num caso como no outro, mas sempre como meio de auscultação de si próprio:

O diário aparece como um espaço de reflexão escrita onde se integram e se misturam 'narrador' e 'coisa narrada', sujeito e factos, o si-próprio e aquele que se narra. $O$ professor-tutor que vai trabalhar em seguida com o aluno-professor, a partir dos dados do seu diário, poderá abordar com ele uma ou outra destas duas dimensões. O autor do diário, tendo conseguido construir uma percepção mais realista do seu próprio vivido, tornar-se-á mais consciente do seu modo de se relacionar com o mundo e da forma como as suas próprias percepções intervêm na realidade profissional (VANCRAYENEST,1990,p.4).

Assim, a escrita desta investigação foi entrecortada por momentos desse diário quase etnográfico, ora apresentado de forma direta no corpo do texto, ora através de convites e pistas para visitar o arquivo: os vídeos, as fotografias, os projetos, os registos de campo, etc. Nas palavras de Zabalza, "escrever sobre o que fazemos como ler sobre o que fizemos nos permite alcançar uma certa distância da acção, e ver as coisas e a nós mesmos em perspectiva" (ZABALZA,2004,p.136). A pertinência do diário, neste caso mais visual, impôs-se sempre que quis "ter um certo distanciamento das coisas que estamos fazendo ou da situação que estamos vivendo", o que me permitiu um "certo controlo sobre a situação objecto da narração" (Ibidem,p.140), que se constitui "como mais um processo de reflexão" que me devolveu um percurso através de uma quase "autoscopia" (NIZA,1997,p.9). Deste modo, a intencionalidade narrativa de experiências profissionais configura-se como a "busca de lucidez", de "uma reflexividade atuante", que procura "orientar individual e coletivamente" as atividades do sujeito-investigador, "suas perspetivas e sua busca de conscientização" (JOSSO,1999,p.14).

Foi neste processo de consciencialização que me movi, graças às leituras e releituras das imagem que fui produzindo, possibilitando-me operar deslocamentos diante da minha zona de conforto. Deste modo, posso dizer que o campo por onde me movi foi gerador de uma atividade reflexiva e cuja perspectiva se autoclarificou pela ação, verbalização oral, escrita ou visual. Daí o uso que fiz da fotografia e do vídeo, como forma de diário, já que como salientei há pouco "todo o objeto só existe no" ou "pelo discurso" (FERNANDES,2002,p.17-18). 
Por conseguinte a imagem neste estudo, através vídeo e a fotografia, sofreu do mesmo tratamento que foi dado ao texto, já que, como produção cultural que é, se torna passível de interpretação como ele. Neste sentido, qualquer pessoa que já tenha escrito "um trabalho académico ou relatórios de pesquisa sabe muito bem que as palavras e os números devem ser disciplinados para que estes possam fazer o que thes é pedido, podendo estes também e mais vezes do que parece, escaparem-se" do alcance do escritor (NEWBURY,2011,p.652). Contudo, se utilizo as metodologias visuais para depois as utilizar como catalisadoras duma reflexão, iluminura de um texto, ou como forma de rever, analisar e transformar as minhas ações, de que me serve disciplinar as minhas imagens? Como salienta Luís Fernandes "definir métodos como esgrimi-los entre si são jogos de linguagem; tenhamos consciência que participamos do jogo, tornemos claro que aceitamos estar de um dos lados da agonística geral (FERNANDES,2002,p.18).

De facto, é num ritmo sem precedentes e cada vez mais com uma diversidade de instrumentos digitais, imagens, sons, palavras, convertidos para formato digital em segundos, que se vêem colocados em causa os princípios capitais da objetividade e neutralidade do ato científico que tendem a omitir, por um lado, a natureza construída e contingente de qualquer interação que se estabelece entre indivíduos, e, por outro, a arbitrariedade dos processos semânticos e retóricos que presidem à fabricação dos enunciados científicos. Assim sendo, as metodologias visuais ao abrirem uma série de novas possibilidades no manuseio, catalogação, manipulação e transporte de dados, promoveram uma maior reflexividade científica em contraposição a um modelo de inspiração positivista, permitindo projetos de pendor colaborativo e possibilitando novos cenários de investigação (PINK,2001,2006; BANKS,1995,2000,2001; MACDOUGALL,1997).

Mas por que exemplos posso eu esclarecer melhor esta ideia?

Foi em 1998 que passamos a saber que podíamos ser mexidos, operados à distância, graças à primeira tele-operação de coração aberto. Foi desta forma que a imagem que tínhamos do nosso corpo mudou, assim como a nossa relação para com a medicina, a doença, a responsabilidade e o sigilo médico. Quando observamos as nossas imagens radiográficas não observamos um corpo, mas nós mesmos. E se a isto pensarmos que agora as imagens do nosso corpo, de nós, nos chegam através de ecografias, tomografias axiais computorizadas, ressonâncias magnéticas ou mesmo de endoscopias, apercebemo-nos de que os nossos órgãos passam a ser agrupados em torno da sua capacidade de criar imagens e não ao contrário. É assim que aos poucos a medicina do visível substitui a medicina do diálogo, da escuta do relato do paciente. O doente desaparece na imagem. Inscreve-se para além dela (SICARD,2006). E esta descrição só faz sentido para percebermos como uma imagem não é inócua, mas sim produtora de 
discurso. É então que mais uma camada de sedimento vem encobrir e delimitar um enunciado, levando-nos a questionar se num mundo social e académico com o nosso, dominado pelos computadores, pela comunicação instantânea e pelos suportes hiper/multimediáticos, continua a fazer sentido perpetuar uma suposta luta entre a palavra e imagem (CAMPOS,2007a,2007b; RIBEIRO,2005)?

Se pensarmos que as oposições nascem de um jogo de tensões conjugadas no seio de uma cultura, de uma organização material e de um desejo de leitura partilhada num determinado contexto, em que um fragmento de cerâmica só é documento se assim o decidirmos, torna-se importante pensarmos que leitura podemos e quereremos fazer das imagens que povoam o nosso arquivo? Que tipo de leitor se deseja ser ou poderemos ser perante estes documentos?

Sabendo que os meios visuais ampliaram as nossas capacidades de manipulação e cruzamento de conteúdos, incentivando a criação de léxicos mais complexos e de produtos polimórficos, este estudo não as entendeu como substitutos da palavra, das suas tecnologias e convenções, antes procurou potenciar as suas características como imagens. Por conseguinte, elas assumiram-se numa contínua negociação do seu papel em função de uma economia de meios e de uma filosofia de pesquisa, que se foi convocando a partir da leitura que fui fazendo do meu problema e dos objetivos da sua integração para a investigação em causa. Neste sentido, quando visualizava os vídeos que tinha feito, quando focava a minha atenção estritamente nas imagens vídeo "para Ihe extrair informação, tornando-a objeto de estudo", o meu objetivo era criar em mim aquilo que Sartre (2006) chamaria de 'consciência refletiva' da imagem (citado em NEWBURY,2011,p.654). Uma consciência que se revelava quando a produção da escrita se iniciava e a imagem fotográfica tomava o lugar da imagem vídeo. Um gesto que se traduzia quando "as imagens são utilizadas como explicação de um argumento ou discussão apresentada no texto", sendo que aqui a argumentação se refere aqueles exemplos onde a imagem, ou mais provavelmente uma "sequência de imagens, está explicitamente projetada para transmitir um argumento" (NEWBURY,2010,p.654).

A propósito desta questão, Martine Joly (2005) refere que se a especificidade da imagem é ser polissémica, é porque qualquer outra coisa que não a imagem não o é. Essa qualquer outra coisa, latente nos primeiros tempos da reflexão sobre a imagem, é a palavra. Implicitamente compara-se a imagem à linguagem verbal e, mais particularmente, à 'palavra'. Mas como a mesma autora refere, a palavra também é polissémica e, não raras as vezes, essa polissemia é propositadamente estimulada para gerar sentidos complexos ou ambíguos. Para autores como John Tagg (2005) ou Monique Sicard (2006), as fotografias são práticas discursivas e, tal como Foucault (1997) colocou, as práticas discursivas não são pura e simples maneiras de produzir discurso. 
Elas estão entranhadas nos dispositivos técnicos, nas instituições, em padrões gerais de comportamento, em formas de transmissão e difusão de conhecimento, assim como em formas pedagógicas que se impõem com o objetivo de levar um sujeito a transformar-se na sua relação consigo. Por esta razão a fotografia não transmite uma realidade préexistente, pois ela própria é criadora de realidades. E como em qualquer sistema discursivo, não nos interessa perguntar o que revela este tipo de discurso/imagem, mas sim que efeito gera. Como é que ele inflete no seu contexto, mais do que aquilo que ele reflete. Que conhecimentos se produzem da reflexão, mais do que se descobrem.

Neste sentido, as imagens, porque polissémicas, devem gerar reflexão tal como as palavras. E a reflexão, a agitação, o devir, é algo que nos move e interessa. Uma imagem não vale por mil palavras pois a sua polissemia além de permitir diferentes leituras, o que a torna subjetiva, obriga-a a interagir com outras, situando-as num determinado contexto para que tenha sentido e possa ser compreendida. Daí que, como apontou Susan Sontag:

Qualquer fotografia tem múltiplos significados; na verdade, para ver algo sob a forma de uma fotografia é encontrar um objeto de fascínio potencial. A sabedoria suprema da imagem fotográfica é dizer: 'Aqui está a superfície. Agora pense - ou melhor, sinta, intua - o que está para além dela, como é que a realidade pode ser se ela se apresenta assim'. Fotografias que não se podem explicar por si são inesgotáveis à dedução, especulação e fantasia" (SONTAG,1977,p.23).

É no campo da esquizofrenia cultural e da invenção do quotidiano que a imagem se move cada vez mais, fazendo parte da nossa cultura visual, de um arquivo de olhares que se globalizou e que faz com que na cultura visual não existam "recetores nem leitores, mas apenas construtores e intérpretes" (HERNÁNDEZ,2003,p.144). Deste modo, o tipo de apropriação que convidei o leitor a fazer dos meus documentos não se inscreveu numa simples relação passiva de dependência, mas pelo contrário como o resultado de uma interação sintonizada com as experiências que cada indivíduo tem vivenciado. E isso, a meu ver, é a "grandeza e a limitação" deste tipo de investigações, mas "é esse o contexto de incerteza em que o investigador aceita situar-se" (ZABALZA,1994:189).

\section{A estória que retiro desta viagem...}

Ao suspender por agora esta viagem em mais uma das suas etapas, não posso deixar de reconhecer nela, quando olho para trás, uma certa prática de deriva. É que lançando-me de um lugar que me era familiar, consegui realizar um percurso onde ao mergulhar a ideia central da investigação no seio da própria dúvida, deixei que a mesma criasse os seus próprios caminhos e os meios se fundissem com os fins. No entanto, as notações e 
diversos registos que fui construindo ao longo da deriva permitiram-me desenhar um mapa pessoal, afetivo e subjetivo do percurso realizado, dando-me a conhecer, através de uma reflexão crítica, as motivações que construíram determinado traçado. Criei assim um arquivo que não foi percebido como um espaço de onde advém uma verdade, mas ele próprio é movimento na sua constituição, um corte duma "lei ali onde os homens e os deuses comandam, ali aonde se exerce a autoridade, a ordem social, nesse lugar a partir do qual a ordem é dada (DERRIDA citado em MARTINS,2011,p.38). Não entendendo o arquivo como um "lugar" fechado mas como uma instância sempre em aberto e interação com os meus conflitos, sujeita a constantes visitações, modificações e acréscimos que permitissem recortar melhor a minha pergunta. Como colocou Foucault, "o arquivo define um nível particular: o de uma prática que faz surgir uma multiplicidade de enunciados como tantos acontecimentos regulares, como tantas coisas oferecidas ao tratamento e à manipulação" (FOUCAULT,2008,p.147).

Por conseguinte, a minha ideia foi refletir por que motivo conectamos um determinado conceito ao outro, dobramos à direita e não seguimos em frente, quais as condições que nos levaram a descansar na margem esquerda e não na direita...enfim, pensar porque determinados mapas conceptuais nos conduzem e produzem uma relação mais intensa connosco ou não. Deste modo, afirmando um comportamento lúdico-construtivo que se distancia em todos os aspetos das noções clássicas de viagem, desde um entendimento psicogeográfico do território por onde me movo, procurei nestas linhas dar a conhecer um espaço de pesquisa onde todos os agentes podem ser leitores e escritores, ou seja, transformadores contínuos do território de ação onde se inscrevem, através duma lógica de autorreflexão partilhada.

A autorreflexão torna-se assim inerente dum trabalho que procura analisar a estória, procurando-Ihe um sentido próprio que não deseje 'traduzir' numa "linguagem douta" um "discurso profano" (CORREIA,1998,p.73). Para isso, cabe ao sujeito mais do querer ser um intérprete entre "partennaires que falam línguas diferentes", desejar ser um tradutor que se auxilie na leitura de si próprio, compreendendo a sua própria língua e colocando no "discurso da comunicação pública, os símbolos de um discurso deformado na linguagem privada". Por tudo isto, o intérprete deve ser capaz de incitar à autorreflexão.

\section{Referências}

BANKS, M. Visual research methods. Social Research Update, n011, 1995. Disponível em: <http://www.soc.surrey.ac.uk/sru/SRU11/SRU11.html> . Acedido em outubro de 2011. 
BANKS, M. Visual anthropology: image, object and interpretation. In: Image-based Research, a Sourcebook for Qualitative Researchers. J. Prosser (eds.). London: Routledge/Falmer, 2000, p.9-23.

BANKS, M. Visual Methods in Social Research. London: Sage Publications, 2001.

BARTHES, R. O rumor da língua. Lisboa: Edições 70, 1987.

BARTHES, R. A preparação do romance, II - a obra como vontade. São Paulo: Martins Fontes, 2005.

BARTHES, R. Lição. Lisboa: Edições 70, 2007.

BARTHES, R. O prazer do texto precedido de Variações sobre a escrita. Lisboa: Edições 70, 2009a.

BARTHES, R. O óbvio e o obtuso. Lisboa: Edições 70, 2009b.

BOURDIEU, P. et al. A miséria do mundo. Petrópolis: Vozes Editora, 2007.

CAMPOS, R. Uma aproximação ao uso do hipermedia na construção de representações antropológicas. In: Antropologia Visual e Hipermedia. J. Ribeiro e S. Bairon (org.). Porto: Afrontamento, 2007a, p. 139-157.

CAMPOS, R. Um exemplo de aplicação do hipermedia em antropologia. In: Imágenes de la Cultura/Cultura de las Imágenes. S. Bairon et al. (org.). Murcia: Editum.es., 2007b, p. 243-253.

CORREIA, J. Para uma teoria crítica em educação: contributos para uma recientificação do campo educativo. Porto: Porto Editora, 1998.

CRISTÓVÃO, F. (coord) et al. O olhar do viajante dos navegadores aos exploradores. Coimbra: Livraria Almedina, 2003.

DELEUZE, G. Crítica e Clínica. Lisboa: Edições Século XXI, 2000.

DELEUZE, G. Foucault. Lisboa: Edições 70, 2012.

DELeuZE, G \& GUATTARI, F. Kafka, Para uma Literatura Menor. Lisboa: Assírio \& Alvim, 2003.

DELEUZE, G \& GUATTARI, F. Mil Planaltos. Capitalismo e esquizofrenia 2. Lisboa: Assírio \& Alvim, 2007. 
FADIGAS, N. Inverter a educação. Porto: Porto Editora, Coleção Mundo de Saberes, 2003.

FERNANDES, L. O sítio das drogas. Lisboa: Editorial Notícias, 2002.

FERNANDES, D.; FERREIRA, M. \& Ó, Jorge. Estudo de avaliação do ensino artístico Relatório Final. 2007. Disponível em: <http://www.min-edu.pt/np3/524.html>. Acedido em março de 2007.

FERRÃO, H. Investigação em Arte. Perspectivas para o século XIX. In: INVESTIGAÇÃo EM ARTE - Uma floresta muitos caminhos, VOL I J. Quaresma; R. Dias \& J. Guadix (Coord.). Lisboa: Edições CIEBA, 2010, p.133-146.

FOUCAULT, M. As palavras e as coisas - uma arqueologia das ciências humanas. São Paulo: Martins Fontes Editora, 1987.

FOUCAULT, M. História da Sexualidade I - A vontade de saber. Lisboa: Relógio d'Água, 1994a.

FOUCAULT, M. História da sexualidade III - O cuidado de si. Lisboa: Relógio d'Água, 1994b.

FOUCAULT, M. A Ordem do Discurso - Aula inaugural no Còllege de France. Lisboa: Relógio d'Água, 1997.

FOUCAULT, M. O que é um autor? Lisboa: Vega, 2006.

FOUCAULT, M. A arqueologia do saber. Rio de Janeiro: Forense Universitária, 2008.

HERNÁNDEZ, F. Educación y cultura visual. Barcelona: Octaedro, 2003.

JOLY, M. A Imagem e os Signos. Lisboa: Edições 70, 2005.

Josso, M. História de vida e projecto: a história de vida como projecto e as "histórias de vida" a serviço de projectos. In: Educação \& Pesquisa, volume 25, n02, 1999, p.11-23.

KAUFMANN, J.C. L'entretien compréhensif. Paris: Nathan, 1996.

LARROSA, J. (1994). Tecnologias do eu e educação. In: O sujeito da educação. Tomaz T. da Silva. Petrópolis: Vozes, 1996, p.35-86.

LARROSA, J. Notas sobre a experiência e o saber de experiência (Conferência proferida no I Seminário Internacional de Educação de Campinas, traduzida e publicada, em julho de 2001, por Leituras SME; Textos-subsídios ao trabalho pedagógico das unidades da Rede Municipal de Educação de Campinas/FUMEC, com publicação autorizada em 2002 
na Revista Brasileira de Educação). Revista Brasileira de Educação, n019, 2002 p.2028. Disponível em: <http://pt.scribd.com/doc/68918965/Jorge-Larrosa-Notas-sobre-aexperiencia $>$. Acedido em outubro de 2013.

LATOUR. B. Why is critique run out of steam? From matters of fact to matters of concern. Critical Inquiry, n030, 2004, p.225-248.

MACDOUGALL, D. The visual in anthropology. In: Rethinking Visual Anthropology.M. Banks e H. Morphy (eds.). New Haven e London: Yale University Press, 1997, p. 276295.

MARTINS, C. As narrativas do génio e da salvação: a invenção do olhar e a fabricação da mão na Educação e no Ensino das Artes Visuais em Portugal (de finais de XVIII até à primeira metade do século XX). Tese de Doutoramento em Educação. Lisboa: Instituto da Educação da Universidade de Lisboa, 2011.

MORAZA, J. A+S, arte y saber. San Sebastián: Arteleku, 2005. Disponível em: $<$ http://www.arteleku.net/programa-es/archivo/arte-y-saber/arte-y-saber $>$. Acedido em setembro de 2012.

NEWBURY, D. Making arguments with images: Visual Scholarship and academic publishing. In: The Sage handbook of visual research methods. E. Margolis \& L. Pauwels (eds.). Los Angeles: SAGE Publications, 2011, p.651-661.

NIETZSCHE, F. O nascimento da tragédia ou mundo grego e pessimismo. Lisboa: Relógio d'Água, 1997.

NIZA, S. Formação cooperada. Lisboa: Educa, Movimento da Escola Moderna Portuguesa e Autor, 1997.

O'DONOGHUE, D. Doing and disseminating visual arts-based approaches. In: The Sage handbook of visual research methods. E. Margolis \& L. Pauwels (eds.). Los Angeles: SAGE Publications, 2011, p.639-650.

PAIVA, J. Acção/Investigação em Educação Artística - em busca de uma narrativa renovada, implicada na construção pertinaz de uma democracia agonística. In: inVisibilidades. Revista Ibero-Americana de Pesquisa em Educação, Cultura e Artes, n03, 2012, p.162-171.

PINK, S. Doing Visual Ethnography - Images, Media and Representation in Research. London: Thousand Oaks, New Delhi, Sage Publications, 2001. 
PINK, S. The Future of Visual Anthropology - Engaging the Senses. London \& Nova Iorque: Routledge, 2006.

PINTO, F.M. Peregrinação. Lisboa: QuidNovi,2008.

POPKEWITZ, T. How the alchemy makes inquiry, evidence and exclusion. In: Journal of TeacherEducation, volume 53, n03, 2002, p.262.

QUARESMA, J. Da investigação e da ambivalência metodológica no munda da arte. In: INVESTIGAÇÃO EM ARTE - Uma floresta muitos caminhos, VOL I. J. Quaresma; R. Dias \& J. Guadix (Coord.). Lisboa: Edições CIEBA, 2010, p.281-307.

QUEIROZ, G. Processos de formação de professores artistas-reflexivos de física. In: Educação \& Sociedade, XXII, n074, 2001, p.97-119. Disponível em: <http://www.scielo.br/pdf/es/v22n74/a07v2274.pdf>. Acedido em outubro de 2012.

RIBEIRO, J. Antropologia visual, práticas antigas e novas perspectivas de investigação. In:Revista de Antropologia, 2005, volume 48, n², p. 613-647.

SICARD, M. A fábrica do olhar. Lisboa: Edições 70,2006.

SONTAG, S. On photography. London: Penguin Books, 1977.

TAGG, J. The Burden of Representation. Essays on photographies and Histories. Minneapolis: University of Minnesota Press, 2005.

VANCRAYENEST, A. A escrita descritiva das práticas educativas como instrumento de mudança. In: Pratiques de formation, n०20, 1990, p.45-56.

VERMERSCH, P. L'entretien d'explicitation. Paris: ESF, 1994.

VIADEL, R. Las investigaciones en educación artística y las metodologías artísticas de investigación en educación: temas, tendencias y miradas. Educação, volume 34, n³, 2011, p. 271-285.

ZABALZA, M. Diários de aula: contributo para o estudo dos dilemas práticos dos professores. Porto: Porto Editora, 1994.

ZABALZA, M. Diários de aula, um instrumento de pesquisa e desenvolvimento profissional. Porto Alegre: Artmed Editora, 2004. 
Joaquim Jesus(UP/Portugal)

Doutor em Educação Artística e Membro Integrado do Núcleo de Educação Artística (nEA), do Instituto de Investigação em Arte, Design e Sociedade (I2ADS), Faculdade de Belas Artes, Universidade do Porto. Endereço: Rua da Aldeia, n.0197 - 4535-295 - Paços de Brandão / Portugal. Endereço eletrônico: joaquimjesus@portugalmail.pt

Recebido em: 25/07/2014

Aprovado em: 08/08/2014 